\title{
Mekanisk embolektomi ved hjerneinfarkt
}
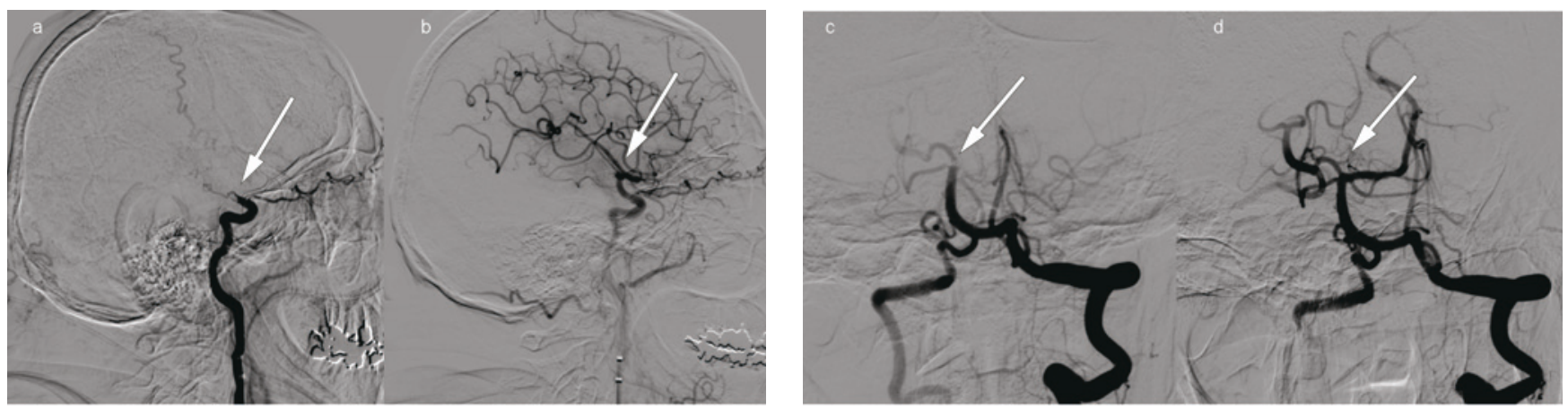

Pasient 1. En mann i 70-årene ble innlagt på grunn av akutt oppståtte høyresidige lammelser. Nevrologiske utfall ble skåret med National Institutes of Health Stroke Scale (NIHSS) til 21 poeng (alvorlig hjerneinfarkt), og intravenøs trombolytisk behandling ble gitt. Bildet til venstre viser cerebral angiografi med kontrastinjeksjon i venstre a. carotis interna, a) før og b) etter embolektomi av en såkalt T-okklusjon (piler) i venstre carotissifongen og a. cerebri media. Tromben ble fjernet og blodstrømmen til venstre hemisfære gjenopprettet etter 195 minutter fra ictus. Utredning viste atrieflimmer og embolisk hjerneinfarkt $i$ a. cerebri medias forsyningsområde. Pasienten fikk antikoagulasjonsbehandling med rivaroksaban. Ved kontroll etter tre måneder var NIHSS-skåren 0 poeng.

Pasient 2. En kvinne i 70-årene fikk etter hjertekirurgi akutt oppståtte høyresidige lammelser, svimmelhet og dysartri. NIHSSskåren var 23 poeng (alvorlig hjerneinfarkt). Intravenøs trombolytisk behandling var kontraindisert. Bildet til høyre viser cerebral angiografi med kontrastinjeksjon i venstre a. vertebralis, c) før og d) etter embolektomi av stor trombe (piler) med okklusjon av a. cerebelli superior, a. cerebri posterior og basilaristoppen. Embolektomi ble utført med rekanalisering 220 minutter etter ictus. Hendelsen oppsto antakelig etter hjertekirurgien. Utredning påviste også atrieflimmer. Pasienten fikk antikoagulasjonsbehandling med warfarin, og ved kontroll etter tre måneder var NIHSS-skåren 0 poeng.

Mekanisk embolektomi på store intracerebrale kar kan være aktuelt både etter intravenøs trombolytisk behandling og $\mathrm{i}$ enkelte tilfeller der dette er kontraindisert (1). Endo- vaskulær revskularisering i fremre (pasient 1) og bakre kretsløp (pasient 2) kan føre til rask klinisk bedring.

Vi mangler gode data som dokumenterer nytteverdien av mekanisk embolektomi versus medikamentell behandling. I flere studier er det rapportert en høyere rekanaliseringsrate etter mekanisk embolektomi (2), mens effekten på funksjonsnivå og mortalitet er omdiskutert (3). Riktig seleksjon kan være avgjørende for det kliniske resultatet. Prosedyren bør foreløpig gjøres innen en registerstudie eller som ledd i en randomisert, kontrollert studie.

Pasientene har gitt samtykke til at artikkelen blir publisert.

\section{Mirza Jusufovic}

mirzajus@hotmail.com

Nevrologisk avdeling

Klinikk for kirurgi og nevrofag

\section{Terje Nome}

Nevroradiologisk enhet

Avdeling for radiologi og nukleærmedisin

Klinikk for diagnostikk og intervensjon

\section{Mona Skjelland}

Nevrologisk avdeling

Klinikk for kirurgi og nevrofag

\section{Eva Astrid Jacobsen}

Nevroradiologisk enhet

Avdeling for radiologi og nukleærmedisin

Klinikk for diagnostikk og intervensjon

Oslo universitetssykehus, Rikshospitalet

Mirza Jusufovic (f. 1980) er lege i spesialisering og forsker på akutt hjerneslag.

Forfatter har fylt ut ICMJE-skjemaet og oppgir ingen interessekonflikter.
Terje Nome (f. 1959) er spesialist i radiologi med spesialkompetanse i nevroradiologisk intervensjon og overlege.

Forfatter har fylt ut ICMJE-skjemaet og oppgir ingen interessekonflikter.

Mona Skjelland (f. 1956) er spesialist i nevrologi og overlege.

Forfatter har fylt ut ICMJE-skjemaet og oppgir ingen interessekonflikter.

Eva Astrid Jacobsen (f. 1957) er dr.med., overlege og fagansvarlig for nevrointervensjon i Oslo universitetssykehus.

Forfatter har fylt ut ICMJE-skjemaet og oppgir ingen interessekonflikter.

\section{Litteratur}

1. Jacobsen EA. Hjerneinfarkt - endovaskulære behandlingsteknikker. Tidsskr Nor Legeforen 2008; 128: 698-702

2. Rha JH, Saver JL. The impact of recanalization on ischemic stroke outcome: a meta-analysis. Stroke 2007; 38: 967-73

3. Broderick JP, Palesch YY, Demchuk AM et al. Endovascular therapy after intravenous t-PA versus t-PA alone for stroke. N Engl J Med 2013; 368: 893-903.

Mottatt 11.6. 2014, første revisjon innsendt 28.5. 2014, godkjent 20.8. 2014. Redaktør: Tor Rosness. 